\title{
Effects of Social Skills and Pedagogig Skills against Preservice Teacher Adaptation Ability Vocational Education
}

\author{
Setiadi Cahyono Putro, Amat Mukhadis, Dwi Agus Sudjimat, \\ Tri Atmadji Sutikno
}

\begin{abstract}
The aim of research in this article is to present the relative contribution and effective are: (1) social skills (X1) to adaptability (Y) partially; (2) the pedagogic skills (X2) to Y partially; and (3) X1 and X2ᄀ to Y simultaneously. This type of research is to expose facto descriptive correlational design. The research was conducted on student teachers TE FT UM force in 2013 a number of 203 respondents. Data pedagogic skills are secondary data (CPI), as for data of social skills revealed using a questionnaire (with a Cronbach's alpha = 0.834 ) and adaptability expressed by a questionnaire (with a Cronbach's alpha $=0.876$ ). The data analysis is based on a multiple linear regression analysis. Results of the study: first, obtained by the regression equation: $Y$ $=0,769 X 1+13,815 X 2-28.164$, and second, the relative contribution of $X 1$ to $Y$ by $82.11 \%$ and $X 2$ to $Y$ by 17.89\%; X1 effective contribution towards $Y$ for $41.05 \%$, and $X 2$ to $Y$ of $8.95 \%$, as well as the X1 and X2 to $Y$ $50.00 \%$. Social skills have a greater effect than the prowess of pedagogical influence on adaptability
\end{abstract}

Keywords: Social Skills, Skills Pedagogic, Adaptive Capabilities, Vocational Teacher.

Social skills

\section{Preliminary}

Social skills are an important part of the ability of human life. Without these skills humans have tidakmulus in interacting with others, so that his life is less harmonious because humans are social creatures who need someone else in his life. Therefore have good social skills will help the man in her life, including the world of work. This is in accordance with the opinion of Combs and Slaby (1977: 162); Merrel and Gimpel (2008: 1) which states that 'social skills is the ability of humans to interact with other human beings in a social context in a special way and socially acceptable and values of the society and at the same time useful for themselves and others.

Libet and Lewinsohn (1973: 304) defines social skill is "the ability both EMIT complex behavior that are positively or negatively reinforced and not to EMIT behaviors that are punished or extinguished by others". That social skills is the ability of the complex to express both positive and negative behaviors and the ability to not express inappropriate behavior and forbidden by others. Johnson and Roger (1999) suggested either the importance of social skills, which is developing the ability to work, productivity, and career success. For example, when students are in the pedagogy program that has good social skills then the student when a teacher would be a good teacher as well. This indicates with good social skills of students, will foster students' ability to adjust to working as a teacher.

Social skills in education, especially the teacher is necessary because in the working environment of teachers are faced with students, peers. So as to become a teacher needed good social skills. This is in accordance with the Law of the Republic of Indonesia No. 14 Year 2005 on Teachers and Lecturers Article 10 which states one of the competencies that must be owned by a teacher is personal competence and social competence.

Aspects of social skills and be a reference in the study proposed by Cartledge and Milburn (1980: 15) split the four-sphere of social skill that is self-related behavior, environmental behaviors, task-related behaviors, and interpersonal behaviors. In this study, aspects of social skills that will be discussed is self-related behavior, task-related behaviors, and interpersonal behaviors.

First, the ability to accept the consequences. Talib (2010: 159), states the ability to accept the consequences of an individual's ability to accept the risk of the act of doing in the social environment. The characteristics of the individual who has the ability to accept the risk that good is being able to listen to opinions or complaints of others, can give or receive feedback (feedback) from the action we did, and it can give or receive criticism.

Second, the ability to express emotion. Nugraha (2011:3) defines emotions as feelings that exist within us, may be feeling happy or not happy, feeling good or bad. This is supported by Lahey (2003) said that emotion is something that is generated by a physiological reaction that led to the emergence of emotions. This reaction can not be read, but can only be seen from the expression and behavior alone. So expressing emotions is the 
ability of individuals to express feelings of both pleasure and bad to others about an event without having to hurt the feelings of others both verbally and non-verbal.

Third, the ability to think positively on yourself. Elfiky (2009: 269) explained that positive thinking is a way of thinking that is more emphasis on the viewpoint and positive emotions well in ourselves, others and the situation at hand. The ability to think positively on themselves according Dwitantyanov (2010: 138), among others, do not give up easily, dare to face the challenge, and confident and learn from problems or difficulties.

Fourth, behave according ada.Kode ethical code of conduct is the norm, rules, ethics in human behavior to do a job in the community (Sudarno, 1989: 117; Lillie, 1996: 2). So behavior in accordance with the code of conduct is an individual act in accordance with the norms, rules, and moral values prevailing in society. Behavior in accordance with the code of conduct can be shown to not violate the law, being an example for others.

Based on the exposure to the above, there are some indications that indicate when a person has self-related behavior that is either: (1) faith or positive thinking to myself; (2) be able to behave in accordance with the applicable rules dimasyaratkat; (3) capable of accepting the consequences of the acts committed; and (4) is able to express the feelings he was experiencing.

Task-related Behavior is a behavior that is associated with the job. The scope of the task-related behavior, namely: (1) the ability to ask and answer questions; (2) cooperation within the group; and (3) the ability to discuss.

First, the ability to ask and answer questions. This capability is one of the skills that must be held by teachers. In asking the question and answer the question there are a few things to note that the language used, the way the questions and answers, and answers to questions are clear and appropriate to the context of the questions asked (Abate and Millan, 1985).

Second, working together in groups. Cooperation is the process of adjusting to the norms, morals, traditions merge into a unity and mutual communication between members of the group (Nurfitriah, 2006: 78). So the ability to work together can be characterized by following the direction of others, do not pull out of the group's activities, follow the rules in the group and so forth.

Third, the ability to think positively of others. This ability is the ability to have good views and emotions in others. For example, do not spread rumors, bad thoughts about others (Dwitantyanov, 2010: 138). Based on the exposure to the above, there is some indication that indicates if a person has good interpersonal behavior, namely: (1) capable of feeling felt by others or bempati on others; (2) capable of communicating with other people with good language, gestures and sounds good; and (3) positive thinking to other people and activities being carried out by that person.

\section{Pedagogic skills}

Proficiency is the impression in the minds of men as a result of her senses and different pengguatan with confidence (beliefes), superstitions (Superstition), and enlightened false (mis-information) (Soekanto, 2003: 8). Meanwhile, Notoatmodjo (2007: 140) argues knowledge (knowledge) is defined as the result of human senses or results "know" a person against its object through the senses (eyes, nose, etc.), by itself when sensing that generate knowledge. So knowledge is the result of human thought obtained from observations of the senses which is then stored in the memory of his brain as it does an impression of observation.

Pedagogic theory is to educate the question what and how to educate as well as possible (Suardi, 1979: 113). Meanwhile, according to the sense in Greek, pedagogy is the science guide the child to discuss any problems or issues in education and educational activities, such as educational, educational tools, how to carry out education, students, educators, and so on. Therefore pedagogic viewed as a process or activity that aims to make people's behavior changes (www.wikipedia.com).

So it can be concluded that, pedagogic skills is an impression in the mind of man as a result of the strengthening of her senses on the theory of educating the question what and how to educate and activities that aim to change human behavior.

In Government Regulation 74 Year 2008 Article 3 stipulated that within the scope of knowledge or understanding of the pedagogical learning theory and principles of learning that educates, understanding of the learners, organize learning that educates, utilization of information and communication technology for learning, understanding of the learning process and results evaluation. The scope of the pedagogical knowledge of teachers needed by student teachers, because in practice, the teacher will be dealing with students, classes, and the learning process and its evaluation. Therefore, to determine the scope of the pedagogical teacher will increase the interest of students to become teachers for the pedagogical scope of this study, the students directly involved in learning activities that explore pedagogical study or teacher. This is in accordance with, the opinion of Hurlock (1995: 144) which states more often we engage in a similar activity will foster interest us against such activity. Thus, by following the lectures that explore pedagogical study or teacher will cause interest to become a teacher. 
Teacher is the human element in education. Teacher is the source of human figures that occupy an important role in education. According Djamarah (2000: 31) teachers in view of the public are carrying out education in certain places, not necessarily in formal educational institutions, but also in mosques, prayer houses and so on. So that prospective teacher is someone who is educated and prepared to become a professional teacher through formal education, non formal and other related activities.

The task of the teacher in the past only to teach a lesson of the book is delivered to students, assign tasks and inspect it. But today obligations / duties of teachers is growing in many respects are working closely with the work of a superintendent, principal, employee administration (Burhanuddin, 2005: 129). So that teachers had a very noble task. The task of the teacher is not only limited to the walls of the school, but also as a liaison between the school and the community. Thus, in any system of teaching, the teacher has always been an integral part, it's just the role it plays will vary according to the demands of the system. The students in acquiring pedagogical skills obtained from the subjects of science and skills (MKK) (TE FT UM, 2014: 2-3).

The implementation of the curriculum in 2013 in Indonesia experienced a culmination point until the end of 2015 and early 2016. Each time the implementation of the new curriculum in Indonesia has always experienced problems related to the readiness of teachers in the field. Readiness less indicates the teacher did not have a good adaptability related changes and new tasks. By because it might have been planned since the adaptability of prospective teachers studying in college.

The first factor which includes the personality, kabilitas, knowledge, creativity, values, attitudes and beliefs, requires further exploration in the research arena in order to create a comprehensive framework in HR management teacher. Research shows that the performance of teachers in teaching is characterized by indicators which vary for example enthusiasm, charismatic, caring, motivation, fair-minded, support, flexibility, outgoing, empathetic, organized, resistant to pressure and adaptable (Hadjam \& Widiarso, 2011). In the context of the performance of teachers in teaching required one indicator, ie adaptable.

\section{Adaptation capabilities}

Adaptation is defined psychological adjustment to share the changing circumstances as to maintain normal function-kan (Brooker, 2001). Another opinion, but expressed similar adaptation is the dynamic process of thoughts, feelings, behaviors and biofisiologic individuals are constantly changing to adapt to the changing environment (Hartanto, 2004). From that sense there is an indication that the adaptation is loading concept of psychological adjustment, cognitive, emotional, behavioral and biofisiologic constantly changing environmental conditions continue to change dynamically.

Schneiders (in Desmita, 2009: 192) adaptation of self is a mental and behavioral responses in which individuals seek to successfully address the needs in her. According Gunarsa in (Alex, 2003: 529) due to a person's response and interaction of individuals or groups with physical and psychological needs. Then the adjustment is always manifested in a response and interaction of the individual to the demands of internal and external

Rivai \& Murni (2010: 214-215) suggests that the ability to adapt to new technology and innovation adaptation of teachers has contributed as a determinant of success related to the teachers' teacher confidence on the ability to organize and carry out the lessons that the need arises to successfully complete the task of teaching specific carefully. Besides, teachers should be able to adapt to the social system in the school where he was in charge. School is an open social system with five essential elements, namely individual, structural, cultural, political, and education. The organization's activities is a function of the interaction of elements in terms of teaching and learning, while the process of teaching and learning is the core technical of the social system of the school, this is a complex process that can be used from three perspectives, namely customs, awareness, and construction (Rivai \& Murni, 2010: 495).

In terms of the adaptability of prospective teachers themselves the responses and interactions include: (1) the response and interaction with himself; (2) the response and interaction towards others, both individually and socially, such as students, colleagues, bosses, employees of the school to the parents of learners; (3) response and interaction to the environment, such as: classroom, school, and lab; (4) responses and interactions of the norms and rules that apply; and (5) as well as the response and interaction of duty.

Vision, mission, and goals of a very important institution of an institution. Due to the vision, mission, and goals that are realistic directions tasked became clear. The study program is an integrated study plan which is organized on the basis of a curriculum with the aim to allow students to master the knowledge, skills, and attitudes in accordance with the formulation of the vision, mission, objectives, and occupational area of competence (TE FT UM, 2014: 1).

\section{Research Purposes}

Based on the presentation above, the purpose of the research in this article are to: present the relative contribution and effective are: (1) social skills towards adaptability partially; (2) the pedagogic skills to partially 
adaptability; and (3) pedagogical and social skills to students simultaneously adaptability. For students of S1 Department of Electrical Engineering, Faculty of Engineering, State University of Malang (Prodi S1 PTE and PTI FT UM). Before revealing the contribution of independent variable to dependent depicting power predictions, the study was preceded by investigating aspects of the relationship between these variables with the alternative hypothesis (Ha) as follows: (1) there is a positive and significant relationship partially between knowledge and pedagogic with adaptability, (2 ) there is a positive and significant relationship between knowledge engineering partially with adaptability, and (3) there is a positive and significant relationship between knowledge simultaneously pedagogic and engineering with adaptability.

\section{Method}

The research method is quantitative expose facto with descriptive correlational design. Base research is the relationship between the independent variables are: (1) social skills (X1) and pedagogical skills (X2) with the dependent variable is the adaptability (Y).

The population in this study is a student of FT UM TE S1 class of 2013. How to determine the sample used is purposive sampling (samples intended), the sampling technique with consideration / certain rational (Sugiyono: 2009: 85). The research sample is addressed to students of the Department of Education Prodi TE force FT UM year 2013, which has completed the Teacher Training PPL odd semester 2016/2017 academic year as many as 203 students.

Data collection instruments and Y variables X1 Likert scale questionnaire with Cronbach's alpha reliability of 0.834 and 0.876 . Data collection for X2 obtained from secondary data. For pedagogical knowledge variable (X2) disclosed on scientific subjects and skills GPA (MKK) as much as 36 credits. Data were obtained from the X2 UM ICT Centre.

Analysis of data using multiple linear regression analysis. For the purposes of achieving research goals uruturutan regression analysis used is as follows. First, melekukan test data analysis requirements, namely: (1) test for normality, (2) linearity, (3) multi-colinearity, and (4) autocorrelation; in this study has been qualified for use parametric statistics (see results). Second, the data entry for the preparation analasisis assisted SPSS regression. Third, enter the SPSS system and identification of the demand for analysis according to the needs of research objectives. Related statistical conclusions in this study based on the level of significance of 0.05 (p.sig $=5 \%$ ).

\section{Description Data \\ Social skills}

\section{Results}

Table 1. Frequency Distribution of Social Skills

\begin{tabular}{|l|l|l|l|l|}
\hline No & Category & Range Score & Frekuency & Precentage \\
\hline 1 & Very high & $104-128$ & 35 & $17 \%$ \\
\hline 2 & High & $80-103$ & 156 & $77 \%$ \\
\hline 3 & Low & $56-79$ & 12 & $6 \%$ \\
\hline 4 & Very low & $32-55$ & 0 & $0 \%$ \\
\hline \multicolumn{2}{|l}{ Total } & 203 & $100 \%$ \\
\hline
\end{tabular}

Based on Table 1 that the social skills of students Prodi Education Department of Electrical Engineering with a very high category and high respectively $17 \%$ and $77 \%$ with a total value of $94 \%$ is in the category of low and very low respectively $6 \%$ and $0 \%$ with a total value by $6 \%$. So that it can be interpreted that the social skills possessed by the students are in the high category.

\section{Pedagogic Skills}

Tabel 2. Frequency Distribution of Pedagogic Skills

\begin{tabular}{|l|l|l|l|l|}
\hline No & Category & Range Score & Frekuency & Precentage \\
\hline 1 & Very high & $3,52-3,79$ & 22 & $11 \%$ \\
\hline 2 & High & $3,25-3,51$ & 93 & $46 \%$ \\
\hline 3 & Low & $2,98-3,24$ & 71 & $35 \%$ \\
\hline 4 & Very low & $2,70-2,97$ & 17 & $8 \%$ \\
\hline \multicolumn{2}{|l}{} & 203 & $100 \%$ \\
\hline
\end{tabular}

Based on Table 2 that the skills of pedagogical students Prodi Education Department of Electrical Engineering with a very high category and high respectively $11 \%$ and $46 \%$ with a total value of $57 \%$ is in the category of low and very low respectively $35 \%$ and $8 \%$ with total value by $43 \%$. So that it can be interpreted that the pedagogic knowledge possessed by students in a category is rather high. 
Effects of Social Skills And Pedagogig Skills Against Preservice Teacher Adaptation Ability ..

\section{Adaptation Capabilities}

Tabel 3. Frequency Distribution of Adaptation Capabilities

\begin{tabular}{|l|l|l|l|l|}
\hline No & Category & Range Score & Frekuency & Precentage \\
\hline 1 & Very high & $101-124$ & 30 & $23 \%$ \\
\hline 2 & High & $78-100$ & 77 & $58 \%$ \\
\hline 3 & Low & $55-77$ & 26 & $19 \%$ \\
\hline 4 & Very low & $31-54$ & 0 & $0 \%$ \\
\hline
\end{tabular}

Based on Table 3 that the interests of students Prodi Education Department of Electrical Engineering to be a teacher with very high category and high respectively $23 \%$ and $58 \%$ with a total value of $81 \%$ is in the category of low and very low respectively $19 \%$, and $0 \%$ with a total value of $19 \%$. So that it can be interpreted that the student interest in the category is rather high.

\section{Test Requirements Analysis}

Kolmorgorov-Smirnov test for normality obtained value (p) for the $\mathrm{X} 1, \mathrm{X} 2$, and Y respectively of 0.726 ; 0.133 ; and 0.460 that these values are above 0.05 , so it can be concluded that the data tested normal distribution. Test linearity between variables (X1 and X2 with Y and Y) $0.000>0.05$. thus the per-requirelinearity between independent variables with dependent met.

Based on the test results of the multi-collieniarity, VIF variables X1 and X2 variable of 3.323 is smaller than 10:00. It can be concluded that there is no problem of multicollinearity between predictor variables.

Based on the autocorrelation between independent variables known that the $\mathrm{D}-\mathrm{W}$ is 1.789 . With reference to the provisions of: (1) number D-W below -2 means there is positive autocorrelation; (2) number D-W between -2 to +2 , meaning no autocorrelation; and (3) number $\mathrm{D}-\mathrm{W}$ above +2 means no negative autocorrelation (Singgih, 2010: 215). It is thus autocorrelation test results are within the provisions of the second with the number D-W is between -2 up to +2 showed no problem autocorrelation between variables X1 and X2.

\section{Hypothesis testing}

Test the hypothesis that reveal partial relationship between the variables of social skills and adaptability is a positive and significant with $r=0,625$ (sig. $=00: 00<0.05$ ) and the partial relationship between pedagogic skills with adaptability was positively and significantly with $\mathrm{r}=0.291(0.000<0.05)$.

Table 4. Summary of Results of Multiple Regression Analysis

\begin{tabular}{|l|l|}
\hline The independent variable & Sig. t \\
\hline Social skills & 0.000 \\
\hline Pedagogic skills & 0.000 \\
\hline R & 0,707 \\
\hline R Square & 0,500 \\
\hline$F_{\text {count }}$ & 100,046 \\
\hline Sig. F & 0,000 \\
\hline
\end{tabular}

Table $4 \mathrm{~F}$ significant value of $0.000<0.05$, thereby simultaneously relationship between variables pedagogical and social skills with adaptability is linear and significant. The results of the analysis to uncover donations between independent and dependent variables, that simultaneously between two independent variables, namely pe-pedagogical knowledge (X1) and knowledge engineering (X2) has effective contribution amounting to $60.60 \%$ of the ability of adap-tation of teacher candidates (Y), with details in a row: the effective contribution of $\mathrm{X} 1$ to $\mathrm{Y}$ by $59.40 \%$ and $\mathrm{X} 2$ to $\mathrm{Y} 1.20 \%$. The relative contribution of a row between the $\mathrm{X} 1$ to $\mathrm{Y}$ is equal to $98.00 \%$ and from $\mathrm{X} 2$ to $\mathrm{Y}$ is at $2.00 \%$.

From table coëficient multiple regression analysis results obtained constant value amounted to -28.164 , coeficient of $0.769 \mathrm{X} 1$ and $\mathrm{X} 2$ coeficient for at 13.815. From these results can be written regression equation $\mathrm{Y}$ $=0.769 \mathrm{X} 1+13,815 \mathrm{X} 2-28.164$. So the predictor function of X1 and X2 to Y simultaneously can be seen from the linear equation. Linearly $\mathrm{Y}$ can be predicted on the increase of one unit together with the X1 X2 unit multiplied by the coefficient of each starting from a constant $-28,164$.

\section{Discussion}

Based on the results of the study indicated it is known that the relationship between social skills dengankemampuan adaptation mrmiliki positive and significant relationship with the degree of strength of the relationship that is or is strong enough. Social skills to be measured on the three categories of social skills of Cartledge and Milburn (1980: 16), namely: (1) self-related behavior; (2) task-related behavior; and (3) interpersonal behaviors. From the research data, obtained indicator is the most dominant task-related behavior which is then followed by the self-related behavior and the last is interpersonal behavior. 
Social skills in education, especially the teacher is necessary because in the working environment of teachers are faced with students, peers. So as to become a teacher needed good social skills. This is in accordance with the Law of the Republic of Indonesia No. 14 Year 2015 on Teachers and Lecturers Article 10 which states one of the competencies that must be owned by a teacher is personal competence and social competence.

When students have the social skills such as the ability to recognize themselves, the ability to comply with existing rules, the ability to cooperate with others, the ability to discuss, the ability to understand others, and the ability to communicate with others, students feel have a stock early enough to be a teacher , Because, students feel controlled two of the four competencies that must be owned by a teacher that is, social competence and personal competence.

By having good social skills will improve the adaptability of students to work as a teacher because the teacher needs to be a good social skills. But, conversely, if students feel less have good social skills, will make the ability to adapt is reduced, because students do not have the ability to feel qualified to be a teacher.

Pedagogical skills possessed by students Prodi TE FT UM Department of Education high uncategorized. This indicates that cognitive student teachers have had sufficient knowledge to plunge into the world of education, of pedagogic aspects. Course knowledge and skills (MKK) teaching-related aspects of preparation, process, and evaluation of learning has owned well.

MKK Education Programs for students Prodi TE FT UM is a reflection of the knowledge or skills sensing results of students to learn such an object lesson planning and others. Sensing results in the form of knowledge or skills that are relevant to the opinion held Notoatmojo (2007: 121) that knowledge is the result out, and this occurred after humans perform sensing on a specific object.

Knowledge or pedagogical skills such high academic value of courses contained in the curriculum of vocational education as a contributor to the value (IP) is the highest, with the lowest score is the subject of educational evaluation. Referring to the translation, the student teachers have enthusiasm for vocational education curriculum subjects but weak in the course of educational evaluation. So it needs a special method for use in suppressing the student teachers lack knowledge of the subject of educational evaluation techniques.

Based on the results of the study stated that the adaptability of student teachers are in very high criteria tend to be high. It is written in the indicator interactions as contributors to the norm and the highest value item interksi indicator to the task as a contributor to the lowest academic value. With reference to the translation, the student teachers Prodi Education Programs UM TE FT has a good ability to adapt to the norms related to the interaction but weak interactions to the task. So that treatment strategies are needed to improve the adaptability of student teachers themselves related to the interaction of the task can be high.

According Schneiders (in Desmita, 2009: 192) adaptation of self is a mental and behavioral responses in which individuals seek to be able to successfully address the needs in him. Adaptability myself holding a very important role in all activities undertaken by student teachers. However student teachers have a background, a way of thinking and a different angle to one another. So the ability to adjust when it is required to be in the neighborhood, as well as the conditions of the new task. Student teachers were introduced to the life of education, engineering and apply it in practice through Practice Field Experience, where student teachers will be introduced significantly to the duties and activities of a lady teacher in the fullest sense. Thus the adaptability of student teachers will be realized through the interaction and response, both to himself, tehadap others, to the environment, to the norms and regulations, as well as the interaction and response to their duties.

Social skills are one skill for know environment well with people and work environment .. Thus, social skills have an impact on the ability to adjust to student teachers in the realm of duties as a teacher of vocational education. Based on the results of the study indicate that there is a positive and significant and moderate correlation with the index. As a predictor of social skills also have pretty strong contribution to the adaptability of prospective teachers. Teachers must have the social skills related learning activities, so that effective learning activities. The research that has been done by Wilayanti (2005: 6) states that the increase in the personal social skills also increase the ability in the desired field. So that it can be used as a basis that social skills have positive influence on the ability to adapt. With increasing social skills it also increases the ability to adapt. The ability to manage the learning activities supported by pedagogical knowledge.

Pedagogic skills is one of knowledge pertaining to the adaptability of student teachers in vocational education. So that pedagogical knowledge is a provision in adapting when carrying out his duties as a teacher someday. Based on the research results show that there is a positive and significant correlation between pedagogic knowledge with the ability to adjust. So any increase in the value of pedagogical knowledge it will also raise the adaptability of the relationships included in the index correlation is very strong. This is because knowledge can be used to support learning adaptability prospective teachers with duties. Thus, the research conducted by Irwan (2012: 53) states that the achievement of an aspect of consciousness can be influenced by the level of knowledge. The level of knowledge contribute to the success of an activity. With the knowledge that everything possible failure in performing an activity can be suppressed to a minimum. So that it can be proved 
that the pedagogical knowledge possessed by student teachers affect the ability to adapt, especially when interacting with their duties. This is consistent with the findings that the pedagogical knowledge has contributed to a more dominant than the adaptability of engineering knowledge.

Pedagogical and social skills is a factor that must be owned by student teachers. Both of such knowledge is an important factor in his job as a vocational teacher. Linkage pedagogical and social skills with the ability to adapt is very real. Social skills to underlie the ability to interact while the pedagogic skills to underlie the ability of adaptation in the field of teacher operational tasks (preparation-process-evaluation). So expect to master both these skills can affect the ability to adapt to preservice-teachers.

Based on research showing that the two variables: the pedagogical and social skills have a positive and significant relationship with student teachers adaptability Prodi Educational Programs TE FT UM and the relationship is in a category index strong correlation with simultaneous effective contribution. It is presented on the preceding discussion, that the combination of pedagogical and social skills have juat contribution to the growth of the capacity of adaptation. So both of these variables can have a significant impact on the ability to adapt simultaneously.

Opinions on the importance of knowledge or skills by Irwan (2012: 53) will be mutually reinforcing the self adaptability (Rizka, 2013: 8). Mutually reinforcing relationship described in this study in regression testing with two predictors. Accordingly, the effect soaial skills and pedagogical skills with the ability to adapt prospective teachers with job it is proved significant.

\section{Conclusions And Suggestions}

Social skills possessed by student teachers are in high category. Pedagogic knowledge possessed by student teachers are in a category rather high. Adaptability student teachers are in a category rather high.

Variable life and social skills as predictors of adaptability pedagogic student teachers Prodi Educational Programs TE FT UM has the following specifications: First, the partial social skills is more dominant than the pedagogic skills, in terms of the magnitude of the correlation coefficient and effective contribution as well as their relative. Second, variables simultaneously pedagogical and social skills have a strong relationship as a predictor of adaptability, and has effective contribution is large enough, ie $50 \%$.

With the findings of this study can be recommended several things related to the adaptability of prospective teachers in terms of pedagogical and social skills. First, to provide adaptability or "softskills another" charge of social skills and learning groups MKK (ability pedagogic) for Prodi Education Department TE FT UM need to improve aspects of the "preparation-process-outcome" learning coherent and equitable for all subjects, because viewed from the side of social skills and cargo MKK association with adaptability is already significant. Third, need to be investigated further to uncover the adaptability of student teachers to bring up the other predictor variables or questionnaire and enhance adaptability to field duty as a vocational teacher.

[1]. Alex, Sobur, 2003. Psikologi Umum. Bandung : Pustaka Setia.

[2]. Abate, L.L dan Milan, M.A. 1985. Handbook of Social Skills Training and Research. New York: John Wisley and Son.

[3]. Arsjad, M dan Mukti. 1988. Pembinan dan Kemampuan Berbicara Bahasa Indonesia. Jakarta: Erlangga.

[4]. Brooker, C. 2001. Kamus Saku Keperawatan. Edisi:31 . Jakarta : EGC.

[5]. Burhanuddin, Yusak. 2005. Administrasi Pendidikan. Bandung: CV Pustaka Setia.

[6]. Cangara. 2011. Pengantar Ilmu Komunikasi. Jakarta: Rajawali Press.

[7]. Cartledge, G dan Milburn, J. 1980. Teaching Social Skill to Chidren Innovative Approaches. New York: Pergamon Press Inc.

[8]. Combs, M dan Slaby, D. 1977. Social Skill Training with Children. New York: Plenum Press.

[9]. Desmita, 2009. Psikologi Perkembangan. Bandung : Remaja Rosda Karya

[10]. Djamarah, Syaiful Bahri. 2000. Guru dan Anak Didik. Jakarta: PT. Rineka Cipta.

[11]. Dwitantyanov, A, dkk. 2010. Pengaruh Berpikir Positif pada Efikasi Diri Akademik Mahasiswa (Studi Eksperimen pada Mahasiswa Fakultas Psikologi UNDIP Semarang). Jurnal Psikologi UNDIP, 8(1): 135-144.

[12]. Elfiky, I. 2009. Terapi Berpikir Positif: Biarkan Mukjizat dalam Diri Anda Melesat Agar Hidup Lebih Sukses dan Lebbih Bahagia. Terjemahan Khalifurrahman Fath \& M. Taufik Darman. Jakarta: Zaman.

[13]. Fakultas Teknik. 2014. Kurikulum Jurusan Teknik Elektro Edisi 2014 Fakultas Teknik Universitas Negeri Malang. (Online), http://ft.um.ac.id/wp-content/uploads/2015/03/Kurikulum-Program-Studi-S1-Pendidikan-Teknik-Informatika-FT-UM-2014.pdf. Diakses pada 25 Mei 2016

[14]. Hadjam, R.N.M., Widhiarso, W. 2011. Efikasi Mengajar Sebagai mediator Peranan Faktor Kepribadian Terhadap Performansi Mengajar Guru. Humanitas, Vol VIII-No1 Januari 2011: 1-16.

[15]. Hurlock, E. 1995. Psikologi Perkembangan Suatu Pendekatan Sepanjang Rentang Kehidupan. Terjemahan Istiwidayanti dan Soedjarwo. Jakarta: Erlangga.

[16]. Irwan, D.F. 2012. Hubungan Tingkat Penghasilan, Tingkat Pendidikan dan Tingkat Pengetahuan Orang Tua Tentang Makanan Bergizi dengan Setatus gizi siswa TK Islam Zahrotul Ulum Karangampel Indramayu. Skripsi tidak diterbitkan. Yogyakarta: Universitas Negeri Yogyakarta.

[17]. Johnson, D. dan Roger , R. 1999. Making Cooperative Learning Work. New York:Lawrence Erlbaum Associates (Taylor \& Francis Group).

[18]. Lahey, B. 2003. Psycology an Introduction (8th ed). New York: Mc Graw Hill.

[19]. Libet. J, dan Lewinsohn, P.M. 1973. The Concept of Social Skill with Special References to Behavior of Depressed Person. Journal of Consulting and Clinical Psycology, 40: 304-312. 
[20]. Lillie, W. 1996. An Introduction to Ethics. New York: Barnes and Noble.

[21]. Merrel, K. dan Gimpel, G. 2008. Social skills of children and adolescent: Conceptualization, assessment, treatment. London: Lawrence Erlbaum Associates, Inc.

[22]. Notoatmodjo, S. 2007. Perilaku Kesehatan dan Ilmu Perilaku. Jakarta: Rineka Cipta.

[23]. Nurfitriah. 2006.Pengembangan Keterampilan Sosial Anak TK Melalui

[24]. Penerapan Metode Pembelajaran Kooperatif. Bandung: UPI.

[25]. Nurihsan, A. 2007. Bimbingan \& Konseling dalam Berbagai Latar Kehidupan. Bandung: PT Revika Aditama.

[26]. Peraturan Menteri Pendidikan Nasional Nomor 16 Tahun 2007 tentang Standar Kualifikasi Akademik dan Kompetensi Guru. 2007. Jakarta: Republik Indonesia.

[27]. Peraturan Pemerintah Nomor 74 Tahun 2008 tentang guru. 2007. Jakarta: Republik Indonesia.

[28]. Rivai, V. Prof. Dr., Murni, S. Dr. 2010. Education Management: Analisis Teori dan Praktik. Jakarta: Rajawali Pers.

[29]. Rizka, A.N. 2013. Hubungan antara Konsep Diri dan Penyesuaian Diri pada Remaja di Islamic Boarding School AMPIT Darul Hikmah Bontang. Artikel Penelitian Tidak diterbitkan. Malang: Universitas Negeri Malang.

[30]. Santrock, John.W. 2011. Psikologi Pendidikan. Terjemahan Tri Wibowo B.S. 2011. Jakarta: Kencana.

[31]. Suardi, E. 1979. Pedagogik. Bandung: Angkasa OFFSET

[32]. Soekanto, S. 2003. Sosiologi Suatu Pengantar. Jakarta: PT Raja Grafindo Persada.

[33]. Soekanto, S. 2003. Sosiologi Suatu Pengantar. Jakarta: PT Raja Grafindo Persada.

[34]. Sudarno, Dkk. 1989. Administrasi Supervisi Pendidikan. Surakarta: Universitas Sebelas Mares Press.

[35]. Sugiyono. 2011. Metode Penelitian Kuantitatif, kualitatif dan $R \& D$. Bandung: Alfabeta

[36]. TEFT UM. 2014. Katalog S1 PTE. Malang: FT UM.

[37]. Thalib, S. 2010. Psikologi Pendidikan Berbasis Analisis Empiris Aplikatif. Jakarta: Kencana.

[38]. Wilayanti, N.W. Pengaruh Keterlibatan dan Kemampuan Teknik Personal pada Efektivitas Penggunaan Sistem Informasi Akutansi dengan Pendidikan dan Pelatihan Sebagai Pemoderasi pada LPD Kecamatan Tegalalang. Skripsi Tidak Diterbitkan. Denpasar. Universitas Udayana.

[39]. Wiyanto. 2004. Seri Terampil Diskusi. Jakarta: PT Raja Grafindo Persada. 